\title{
Fauna Biodiversity as Indicator of Mangrove Forest Health on Moti Island, Moti District, Ternate City
}

\author{
Salim Abubakar ${ }^{*}$, Masykhur Abdul Kadir ${ }^{1}$, Reni Tyas Asrining Pertiwi ${ }^{1}$, Rina ${ }^{1}$, Riyadi \\ Subur $^{1}$, Sunarti ${ }^{1}$, Yuyun Abubakar ${ }^{1}$, Adi Noman Susanto ${ }^{1}$, Ariyati H. Fadel ${ }^{1}$ \\ ${ }^{1}$ Program Studi Manajamen Sumberdaya Perairan, FPIK Universitas Khairun Ternate, Indonesia
}

\author{
Article History \\ Received : August $30^{\text {th }}, 2021$ \\ Revised : September $20^{\text {th }}, 2021$ \\ Accepted : September $30^{\text {th }}, 2021$ \\ Published : October $12^{\text {th }}, 2021$ \\ *Corresponding Author: \\ Salim Abubakar, \\ Program Studi Manajemen \\ Sumberdaya Perairan FPK \\ Universitas Khairun Ternate, \\ Ternate, Indonesia; \\ Email: \\ mylasrinaldy@gmail.com
}

\begin{abstract}
The health condition of mangrove forests can be determined by assessing forest health indicators. One of the indicators used in determining the health of mangrove forests is fauna biodiversity. Measurement of forest health is a step that can be taken to ensure forest functions and benefits. The study's objectives were to determine the composition of mangrove species and mangrove forest fauna (birds and epifauna), to determine the structure of the fauna community which includes species diversity and species dominance and to determine the health condition of mangrove forests on Moti Island, Ternate Island District. This research was conducted on Moti Island, Moti District, Ternate City, North Maluku Province for six months, April - September 2021. A Sampling of mangroves was carried out using the "spot check" method. Meanwhile, the method used to assess mangroves' health condition refers to the FHM (Forest Health Monitoring) method. There are nine species of mangrove, namely Rhizophora apiculata, Rhizophora stylosa, Rhizophora mucronata, Bruguiera gymnorrhiza, Sonneratia alba, Xylocarpus granatum, Avicennia offincinalis, A. marina and Nypa fruticans. While the composition of fauna species is as many as 18 species consisting of Epifauna (Gastropoda $=12$ species, Bivalve $=2$ species ) and birds as many as four species. The diversity of mangrove forest fauna species in all research locations is moderate and no species dominate. The health status of mangrove forests, both Tafaga and Figur villages, has $60 \%$ good condition, $20 \%$ moderate and poor conditions.
\end{abstract}

Keywords: fauna diversisty, mangrove forest health, Moti island

\section{Pendahuluan}

Hutan mangrove merupakan tumbuhan yang dipengaruhi pasang surut dan tolerans terhadap salinitas, lama penggenangan dan substrat. Hutan Mangrove memberikan kontribusi bagi kehidupan biota, komponen abiotik (substrat dan perairan) dan kehidupan masyarakat. Produktivitas dan kelangsungan hidup biota bergantung pada kesehatan tegakan mangrove. Rantai makanan dalam hutan mangrove berassal dari guguran serasah sebagai sumber utama bahan organik untuk mendukung kehidupan ekologi pada hutan mangrove. Kondisi ekologi yang baik dapat mempengaruhi kelimpahan maupun keanekaragaman jenis biota yang menjadikan mangrove sebagai habitat dan tempat berkembang biak (Chen et al., 2020; Dharmawan et al., 2020). Fauna hutan mangrove terdiri dari kelompok fauna daratan (burung, ular, biawak, monyet, harimau) dan fauna perairan yang hidup pada kolom air (ikan, udang, kepiting, buaya) dan substrat (bivalva, gastropoda) serta menempel pada akar, batang dan daun (Abubakar et al., 2018, Hasan et al., 2020).

Banyaknya fungsi dan manfaat yang dapat diperoleh dari hutan mangrove yaitu sebagai tempat pemijahan (spawning ground), daerah asuhan (nursery ground),dan daerah untuk mencari makan (feeding ground) bagi ikan dan biota laut lainnya, menahan gelombang laut dan intrusi air laut kearah darat. Kelestarian hutan mangrove dapat terjaga dengan baik apabila kesehatan hutan mangrove selalu diperhatikan. Kesehatan hutan mangrove memiliki hubungan erat dengan penutupan areal vegetasi, sedangkan kesehatan hutan hubungannya dengan kondisi tegakan dan manfaat yang diperoleh (Rospita et al., 2017; Apriliyani et al., 2020). 
Biodiversitas (keanekaragaman jenis) fauna merupakan salah satu indikator dalam menentukan kondisi kesehatan hutan mangrove. Dalam menjamin fungsi dan manfaat hutan, langkah yang hrus dilakukan adalah melakukan pengukuran kesehatan hutan (Sari et al., 2019). Penelitian kesehatan hutan mangrove umumnya di Indoenesia belum banyak dilakukan dan khususnya di wilayah Maluku Utara belum pernah dilakukan. Beberapa hasil penelitian tentang kesehatan mangrove yang telah dilakukan oleh Sari et al (2019) dan Apriliyani et al (2020). Sedangkan di wilayah Maluku Utara penelitian mangrove masih terbatas pada asosiasi dan relung mikrohabitat gastropoda (Abubakar et al., 2018), kesesuaian lahan konservasi (Widiyanti et al., 2018), kesesuaialan lahan ekowisata (Abubakar et al, 2019), distribusi fauna (Hasan et al., 2020), struktur vegetasi (Serosero et al, 2020) dan tingkat kerusakan dan kesesuaiaan lahan rehabilitasi (Abubakar et al, 2020),

Pulau Moti Kecamatan Pulau Ternate merupakan salah satu pulau yang memiliki ekosistem hutan mangrove yang tumbuh di seluruh daerah pesisirnya. Namun kondisinya sudah mengalami kerusakan karena berbagai aktivitas kegiatan antropogenik yang dilakukan oleh masyarakat berupa pengambilan kayu bakar, bahan bangunan, pendaratan perahu dan konversi lahan sebagai lahan pemukiman dan jalan raya. Kerusakan tersebut akan berdampak pada kesehatan hutan mangrove terutama komposisi dan habitat jenis mangrove, keanekaragaman jenis fauna dan juga tentunya sangat berpengaruh kepada pendapatan nelayan yang memanfaatkan hutan mangrove sebagai daerah penangkapan ikan. Salah satu penyebab kerusakan hutan mangrove adalah rendahnya kesadaran masyarakat akan fungsi dan peranan hutan mangrove.

Kondisi kesehatan hutan mangrove berperan penting terhadap keberlanjutan ekosistem hutan mangrove. Olehnya itu, perlu pengkajian tentang biodiversitas fauna sebagai indikator dalam menentukan status kondisi kesehatan hutan mangrove. Tujuan penelitian yaitu menentukan komposisi jenis mangrove dan fauna hutan mangrove (burung dan epifauna), menentukan struktur komunitas fauna dan nenentukan kondisi kesehatan hutan mangrove di Pulau Moti Kecamatan Pulau Ternate.

\section{Bahan dan Metode}

\section{Tempat dan Waktu Penelitian}

Penelitian dilaksanakan di Pulau Moti Kecamatan Moti Kota Ternate Propinsi Maluku Utara. pada bulan April - September 2021.

\section{Prosedur Pengambilan Data}

\section{Penentuan Stasiun}

Stasiun penelitian terdiri dari 2 stasiun berdasarkan aktivitas kegiatan antropogenik yang dilakukan oleh masyarakat, dimana Stasiun 1 (Kelurahan Tafaga) dengan bentuk kegiatan antropogenik berupa pengambilan kayu bakar, bahan bangunan, pendaratan perah, konversi lahan sebagai jalan raya dan pemukiman. Sedangkan Stasiun 2 (Kelurahan Figur) dengan bentuk kegiatan antropogenik berupa pengambilan kayu bakar, bahan bangunan dan pendaratan perahu.

\section{Vegetasi Mangrove}

Pengambilan data vegetasi dengan metode "spot check" (Abubakar dan Ahmad, 2013). Data diambil saat surut terendah dengan menggunakan transek garis secara vertikal. Lintasan terdiri dari 5 buah dengan penempatan plot sebanyak 5 buah plot. Selanjutnya setiap transek ditempatkan plot berukuran $10 \mathrm{~m} \times 10 \mathrm{~m}$ sebanyak 5 buah. Identifikasi vegetasi mangrove berdasarkan ciriciri daun, bunga, buah dan akar sesuai petunjuk Noor et al (2012).

\section{Kesehatan Mangrove}

Penilaian kondisi kesehatan mangrove mengacu pada panduan FHM (Forest Helath Monitoring) yang dipakai dalam penentuan penilaian kesehatan dan kondisi ekosistem. Pengambilan data biodiversitas fauna (burung dan epifauna) sebagai indikator kesehatan hutan mangrove dengan menggunakan metode klaster dan setiap klaster terdiri dari empat plot. Setiap stasiun terdiri dari 5 klaster, sehingga jumlah total plot sebanyak 20 plot tiap stasiun (Mangold, 1997). Metode FHM untuk pengamatan fauna disajikan pada gambar 1 . 


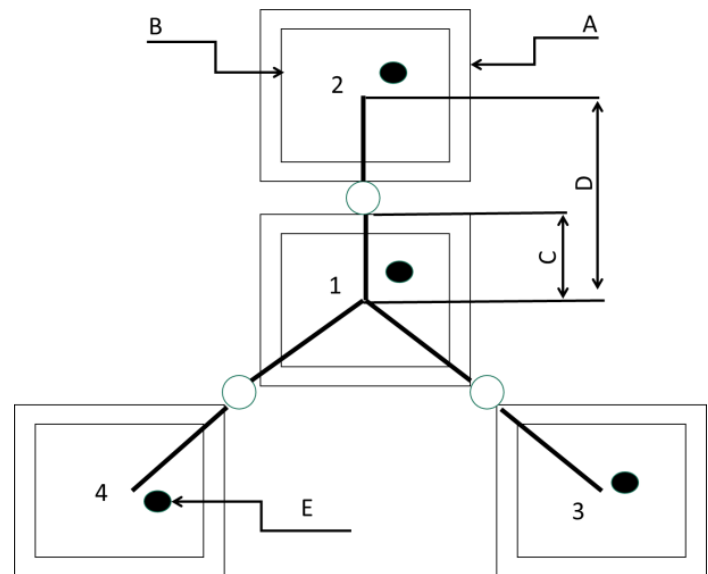

Gambar 1. Desain klaster-plot FHM (Sari et al., 2019) modifikasi (2021)

Keterangan $\mathrm{A}=$ blok area $20 \times 20 \mathrm{~m}, \mathrm{~B}=$ subplot 15 x $15 \mathrm{~m}, \mathrm{C}=$ Jarak antar subplot $(10 \mathrm{~m}), \quad \mathrm{D}$ $=$ Jarak antara titik pusat plot $(30 \mathrm{~m}), \mathrm{E}=$ mikro plot $(2 \times 2 \mathrm{~m})$.

Pengamatan burung dilakukan pada pagi $(08.00-10.00$ WIT $)$ dan sore hari $(14.00-18.00$ WIT) dan hanya pada plot 1 , guna menghindari agar tidak terjadi pengulangan perhitungan. Sedangkan pengambilan sampel epifauna pada sedimen, akar, batang, ranting dan daun pada masing-masing mikro plot $(2 \times 2 \mathrm{~m})$ sebanyak 5 buah setiap sub plotnya. Dalam tapahan identifikasi, epifauna yang telah diperoleh selanjutnya diawetkan dengan larutan formalin $10 \%$ (alkohol 70\%). Identifikasi dengan menggunakan Dharma (2005).

\section{Prosedur Analisa Data}

\section{Struktur Komunitas Fauna}

Keanekaragaman Jenis $\left(\mathrm{H}^{\prime}\right)$

Keanekaragaman jenis menggunaka metode Shannon dan Wiener (Rondo, 2015) :

$$
H^{\prime}=-\sum_{i: 1}^{s} \frac{n i}{N} \ln \frac{n i}{N}
$$

Keterangan:

$\mathrm{H}=$ Keanekaragaman jenis

$\mathrm{ni}=$ Jumlah individu jenis-i

$\mathrm{N}=$ Jumlah seluruh individu

Dengan kriteria : $H^{\prime}<1$ (keanekaragaman jenis rendah), $1 \leq H^{\prime} \leq 3$ (keanekaragaman jenis sedang), $H^{\prime}>3$ (keanekaragaman jenis tinggi)

\section{Dominansi Jenis $(C)$}

Dominansi spesies berdasarkan petunjuk Rondo (2015):

$$
C=\sum\left(\frac{n i}{N}\right)^{2}
$$

Keterangan :
$\mathrm{C}=$ Dominansi jenis

$\mathrm{ni}=$ Jumlah individu tiap jenis

$\mathrm{N}=$ Jumlah individu seluruh jenis

Dengan kriteria :

Nilai $\mathrm{C}$ berkisar $0-1$. Jika $\mathrm{C}(1-0,49)=$ tidak ada spesies yang mendominasi dan $\mathrm{C}(0,50-$ $1,00)=$ ada salah satu spesies yang mendominasi.

\section{Kesehatan Mangrove}

Penentuan nilai skoring berdasarkan nilai indeks keanekaragaman, dimana status kondisi mangrove yang baik dengan skor tertinggi, Kategori meliputi baik, sedang dan jelek. Hasil perkalian nilai tertimbang dan nilai skor parameter diperoleh analisis kondisi kesehatan pada tiap klaster plot (Safe'i dan Tsani, 2016). Nilai tertimbang yaitu 0,33 untuk indikator biodiversitas fauna dan kondisi kesehatan hutan mangrove dihitung dengan menggunakan formula (Sari et al., 2019):

$$
N K H m=\sum(N T x N S)
$$

Keterangan:

NKHm = Nilai akhir kondisi kesehatan hutan mangrove

NT = Nilai tertimbang parameter

NS = Nilai skor parameter

Dengan kriteria : 0,30 - 0,79 (kondisi jelek), 0,77 - 1,20 (kondisi sedang) dan 1,20 - 1,65 (kondisi baik).

\section{Hasil dan Pembahasan}

\section{Komposisi dan Distribusi Jenis Mangrove}

Komposisi jenis mangrove sebanyak 5 famili (Rhizophoraceace, Sonneratiaceae, Meliaceaea, Avicinneaceae, Areacaceae), 6 genus (Rhizophora, Sonneratia, Xylocarpus, Avicennia, Nypa) dan 9 jenis yaitu Avicennia marina, A. offincinalis, Nypa fruticans Bruguiera 
gymnorrhiza, Sonneratia alba, Rhizophora apiculata, $R$. stylosa, $R$. mucronata dan Xylocarpus granatum (Tabel 1).

Tabel 1. Komposisi jenis mangrove

\begin{tabular}{|c|c|c|c|c|c|c|}
\hline \multirow{2}{*}{ No. } & \multirow{2}{*}{ Famili } & \multirow{2}{*}{ Jenis } & \multicolumn{2}{|c|}{ Nama } & \multicolumn{2}{|c|}{ Desa } \\
\hline & & & Indonesis & Lokal & Tafaga & Figur \\
\hline 1 & \multirow{2}{*}{ Avicenniaceae } & Avicennia officinalis & Api-api & Wika-wika & - & + \\
\hline 2 & & Avicennia marina & Api-api & Wika-wika & + & - \\
\hline 3 & \multirow[t]{2}{*}{ Arecaceae } & Nypa fruticans & Nipah & Bobo & + & + \\
\hline 4 & & Rhizophora apiculata & Bakau kacang & Halaro & + & + \\
\hline 5 & \multirow{3}{*}{ Rhizophoraceae } & Rhizophora stylosa & Bakau & Halaro puha & + & + \\
\hline 6 & & Rhizophora mucronata & Bakau hitam & Halaro & - & + \\
\hline 7 & & Bruguiera gymnorrhiza & Tanjang merah & Dau & + & + \\
\hline 8 & Sonneratiaceae & Sonneratia alba & Pedada & Posi-posi & + & + \\
\hline 9 & Meliaceae & Xylocarpus granatum & Kira-Kira & Tanga & - & + \\
\hline
\end{tabular}

Keterangan : + = Ada, $-=$ tidak ada

Komposisi jenis mangrove lebih tinggi pada famili Rhizophoraceae yaitu 4 jenis dan terendah pada Sonneratiaceae, Meliaceae dan Arecaceae masing-masing sebanya 1 jenis. Perbedaan komposisi jenis disebabkan oleh kecocokan habitat dan kegiatan antropogenik yang dilakukan oleh masyarakat. Famili Rhizophoraceae ditemukan pada substrat lumpur, pasir, pasir bercampur patahan karang dan lumpur berpasir. Abubakar et al (2018), menyatakan substrat sangat berpengaruh terhadap kehidupan mangrove. Rhizophora mucronata merupakan vegetasi dominan pada substrat berlumpur dalam, sedangkan berlumpur dangkal di dominasi oleh Rhizophora apiculata dan Bruguiera sp. Rhizophora stylosa dominan pada substrat pasir bercampur karang mati.

Aktivitas antropogenik merupakan faktor dalam menentukan kehidupan dan kelestarian ekosistem mangrove. Kelurahan Tafaga berupa pengambilan kayu bakar, bahan bangunan, pendaratan perahu, konversi lahan sebagai jalan raya dan pemukiman. Sedangkan di Kelurahan Figur pengambilan kayu bakar, bahan bangunan dan pendaratan perahu. Kerusakan mangrove selain faktor alamiah (bio-fisik) juga disebabkan oleh aktivitas antropogenik berupa pengambilan kayu bakar, bahan bangunan, aksesoris rumah tangga dan pembuangan sampah. Sampah padat dapat berakibat tertutupnya pneumatofora pada akar mangrove sehingga mangrove mengalami kematian. Konversi lahan secara komersial dapat mengancam regenerasi stok ikan dan udang di perairan yang membutuhkan hutan mangrove sebagai daerah asuhan, mencari makan dan pembesaran (Rusdianti dan Sunito, 2012; Hartati dan Harudu, 2016; Simbala et al., 2017; Abubakar et al., 2020; Abubakar et al., 2021).

\section{Komposisi dan Distribusi Jenis Fauna Hutan Mangrove}

Komposisi jenis fauna hutan mangrove sebanyak 18 jenis yang terdiri dari kelas gastropoda sebanyak 12 jenis (Cerithium cingulate, Telescopium telescopium, Terebralia sulcata, Chicoreus capucinus, Strombus luhuanus, Littorina scabra, Littorina undulata, Nerita undata, Nerita costata, Nerita planospira, Turbo agryrostoma, Turbo breneus), kelas bivalva sebanyak 2 jenis (Polymesoda expansa, Polymesoda erosa) dan kelas aves/burung sebanyak 4 jenis (Haliastur indus, Butorides striatus, Pelargopsis capensis, Copsychus saularis). Komposisi dan distribusi jenis fauna hutan mangrove disajikan pada tabel 2.

Tabel 2. Komposisi dan distribusi jenis fauna hutan mangrove

\begin{tabular}{|c|c|c|c|c|c|}
\hline \multirow{2}{*}{ No. } & \multirow{2}{*}{ Famili } & \multirow{2}{*}{ Genus } & \multirow{2}{*}{ Spesies } & \multicolumn{2}{|c|}{ Stasiun } \\
\hline & & & & Tafaga & Figur \\
\hline \multicolumn{6}{|c|}{ Kelas Gastropoda } \\
\hline 1 & Potamididae & Cerithidea & Cerithidea cingulata & + & + \\
\hline
\end{tabular}




\begin{tabular}{|c|c|c|c|c|c|}
\hline 2 & & Telescopium & Telescopium telescopium & - & + \\
\hline 3 & & Terebralia & Terebralia sulcata & + & + \\
\hline 4 & Muricidae & Chicoreus & Chicoreus capucinus & + & + \\
\hline 5 & Strombidae & Strombus & Strombus luhuanus & - & + \\
\hline 6 & \multirow{2}{*}{ Littorinidae } & \multirow{2}{*}{ Littorina } & Littorina scabra & + & + \\
\hline 7 & & & Littorina undulata & + & - \\
\hline 8 & \multirow{3}{*}{ Neritidae } & \multirow{3}{*}{ Nerita } & Nerita undata & + & + \\
\hline 9 & & & Nerita costata & + & + \\
\hline 10 & & & Nerita planospira & - & + \\
\hline 11 & \multirow{2}{*}{ Turbinidae } & \multirow{2}{*}{ Turbo } & Turbo agryrostoma & - & + \\
\hline 12 & & & Turbo breneus & + & + \\
\hline \multicolumn{6}{|c|}{ Kelas Bivalva } \\
\hline 13 & Cyrenidae & \multirow{2}{*}{ Polymesoda } & Polymesoda expansa & + & + \\
\hline 14 & Corbiculidae & & Polymesoda erosa & + & + \\
\hline \multicolumn{6}{|c|}{ Kelas Aves (Burung) } \\
\hline 15 & Accipitridae & Haliastur & Haliastur indus & - & + \\
\hline 16 & Ardeidae & Butorides & Butorides striatus & + & - \\
\hline 17 & Halcyonidae & Pelargopsis & Pelargopsis capensis & + & + \\
\hline 18 & Muscicapidae & Copsychus & Copsychus saularis & + & + \\
\hline
\end{tabular}

Keterangan : + = Ada, - = tidak ada

Tabel 2 menunjukkan Kelurahan Tafaga memiliki komposisi jenis fauna sebanyak 13 jenis dan Kelurahan Figur sebanyak 16 jenis. Perbedaan komposisi jenis fauna tersebut, disebabkab oleh kerapatan dan ketebalan hutan mangrove, dimana Kelurahan Figur dengan kerapatan dan ketebalan mangrove $(50-200 \mathrm{~m})$ lebih tinggi dibandingkan dengan Kelurahan Tafaga dengan ketebalan $10-150 \mathrm{~m}$ ). Tingginya kepadatan organisme hutan mangrove sangat erat hubungannya dengan kerapatan dan ketebalan hutan mangrove, karena kerapatan dan ketebalan dapat menyediakan habitat dan tempa pemijahan bagi organisme untuk dapat berkembang dan tempat bersarangnya jenis burung (Abubakar et $a l, 2019)$. Kepadatan biota berhubungan sangat erat dengan kerapatan mangrove, semakin rapat vegetasi mangrove maka kepadatan biota akan tinggi (Wahyudyawati et al., 2017).

\section{Struktur Komunitas Fauna Hutan Mangrove}

Struktur komunitas fauna hutan mangrove disajikan pada tabel 2 dan 3. Nilai keanekaragaman jenis fauna hutan manrove
Kelurahan Tafaga yaitu $\mathrm{H}^{\prime}=1,9790$ dan dominansi jenis $(\mathrm{C}=1,9790)$. Sedangkan keanekaragaman jenis fauna hutan mangrove di Kelurahan Figur $\left(\mathrm{H}^{\prime}=2,8871\right)$ dan dominansi jenis $(C=0,3326)$. Keanekaragaman jenis fauna hutan mangrove di semua lokasi penelitian kategori sedang dan dominasi rendah atau tidak ada yang mendominasi. Rondo (2015) menyatakan bahwa nilai keanekaragaman jenis antara $1 \leq H^{\prime} \leq 3$ maka tergolong sedang jika $\mathrm{C}$ (1 $-0,49)=$ tidak ada spesies yang mendominasi dan C $(0,50-1,00)=$ ada salah satu spesies yang mendominasi.

Keanekaragaman jenis fauna tertinggi terdapat di Kelurahan Figur, disebabkan karena jumlah spesies (16 spesies) dan jumlah individu (3625 indvidu) lebih banyak bila dibandingkan dengan Kelurahan Tafaga dengan jumlah spesies sebanyak 13 spesies dengan jumlah individu sebanyak 2291 individu. Selain itu dipengaruhi oleh aktivitas antropogenik yang sudah berkurang sehingga kondisi ekosistem hutan mangrove dapat terjaga dengan baik.

Tabel 2. Keanekaragaman jenis (H') dan dominansi jenis fauna hutan mangrove Kelurahan Tafaga

\begin{tabular}{ccccc}
\hline No & Jenis & $\mathrm{H}^{\prime}$ & $\mathrm{C}$ \\
\hline 1 & Cerithidea cingulata & 0.2380 & 0.0113
\end{tabular}




\begin{tabular}{clll}
2 & Terebralia sulcata & 0.3679 & 0.1341 \\
3 & Chicoreus capucinus & 0.2135 & 0.0077 \\
4 & Littorina scabra & 0.2839 & 0.0223 \\
5 & Littorina undulata & 0.1055 & 0.0009 \\
6 & Nerita undata & 0.2129 & 0.0076 \\
7 & Nerita costata & 0.0478 & 0.0001 \\
8 & Turbo breneus & 0.2065 & 0.0069 \\
9 & Polymesoda expansa & 0.1087 & 0.0010 \\
10 & Polymesoda erosa & 0.1109 & 0.0010 \\
11 & Butorides striatus & 0.0312 & 0.0000 \\
12 & Pelargopsis capensis & 0.0177 & 0.0000 \\
13 & Copsychus saularis & 0.0347 & 0.0000 \\
\hline \multicolumn{2}{r}{ Jumlah } & 1,9790 & 0,1930 \\
\hline
\end{tabular}

Tabel 3. Keanekaragaman jenis (H') dan dominansi jenis fauna hutan mangrove Kelurahan Figur

\begin{tabular}{clcc}
\hline No & & Jenis & $\mathrm{C}$ \\
\hline 1 & Cerithidea cingulata & 0.2952 & 0.02637 \\
2 & Telscopium telescopium & 0.3651 & 0.10490 \\
3 & Terebralia sulcata & 0.3677 & 0.12686 \\
4 & Chicoreus capucinus & 0.1909 & 0.00531 \\
5 & Strombus luhuanus & 0.1077 & 0.00096 \\
6 & Littorina scabra & 0.2262 & 0.00939 \\
7 & Nerita undata & 0.0954 & 0.00069 \\
8 & Nerita costata & 0.1291 & 0.00161 \\
9 & Nerita planospira & 0.1747 & 0.00401 \\
10 & Turbo agryrostoma & 0.2190 & 0.00840 \\
11 & Turbo breneus & 0.1822 & 0.00458 \\
12 & Polymesoda expansa & 0.1192 & 0.00128 \\
13 & Polymesoda erosa & 0.3188 & 0.03807 \\
14 & Haliastur indus & 0.0312 & 0.00004 \\
15 & Pelargopsis capensis & 0.0430 & 0.00008 \\
16 & Copsychus saularis & 0.0218 & 0.00002 \\
\hline & $\quad$ Jumlah & 2,8871 & 0,3326 \\
\hline
\end{tabular}

Hutama et al (2019) menyatakan komunitas yang memiliki jenis dan jumlah individu sedikit maka keanekaragaman yang diperoleh rendah. Sedangkan bila dalam komunitas dengan Keanekaragaman sedang maka terjadinya bentuk interaksi antar spesies berupa kompetisi, produktivitas cukup, kondisi ekosistem sangat stabil dan tekanan ekologis yang sedang. Mardi et al (2019), menyatakan faktor utama yang mempengaruhi jumlah organisme, keragaman jenis dan dominansi antara lain adanya perusakan habitat alami seperti pengkonversian lahan, pecemaran kimia dan organik, serta perubahan iklim.

\section{Kondisi Kesehatan Hutan Mangrove}

Nilai Keanekaragaman fauna (burung dan epifauna) digunakan untuk mengetahui kondisi kesehatan hutan mangrove. Keanekaragaman jenis fauna yang terdapat di hutan mangrove Kelurahan Tafaga sebanyak 13 jenis yang terdiri dari Epifauna (Gastropoda $=8$ jenis, Bivalva $=2$ jenis) dan burung sebanyak 3 jenis (Butorides striatus, Pelargopsis capensis, Copsychus saularis). Sedangkan di Kelurahan Figur, keanekaragaman jenis fauna sebanyak 16 jenis yang terdiri dari Epifauna (Gastropoda $=11$ jenis, Bivalva $=2$ jenis) dan burung sebanyak 3 jenis (Haliastur indus, Pelargopsis capensis, 
Copsychus saularis). Setiap klaster plot ditemukan jenis burung dan epifauna yang relatif sama.

Burung kacer (Copsychus saularis) dan elang bondol (Haliastur indus) umumnya ditemukan dalam klaster plot. Burung kacer di temukan di substrat sedang memakan cacing dan juga di dahan memakan buah mangrove. Sedangkan elang bondol ditemukan pada ujung dahan mangrove Menurut Sari (2012), burung kacer lebih menyukai area terbuka di pinggiran hutan. Makanan utama burung ini adalah serangga, cacing, buah-buahan dan madu. Sedangkan elang bondol Termasuk kelompok karnivora yaitu memangsa mamalia kecil seperti tikus, ular katak dan sebagainya. Keanekaragaman jenis burung yang ditemukan tersebut, menunjukkan kedua lokasi penelitian memliki kondisi hutan mangrove yang masih terjaga. Angriana et al. (2018) menyatakan bahwa burung dijadikan sebagai komponen utama dalam kesehatan mangrove karena memiliki hubungan timbal balik dan bergantung dengan habitatnya.

Kelompok epifauna yang selalu terdapat di klaster plot adalah dari family Potamididae yaitu Terebralia sulcata dan Telescopium telescopium. Kedua jenis ini umumnya ditemukan diatas substrat dan jenis Terebralia sulcata ditemukan memanjat akar dan batang pohon mangrove. Menurut Abubakar et al (2018)) bahwa famili potamididae adalah fauna dominan dan penghuni asli hutan mangrove, yang memiliki pola adaptasi tertentu agar dapat bertahan dalam hutan mangrove. Selama tidak melakukan aktivitas, Telescopium telescopium berlindung dengan mengubur diri dalam lumpur sedangkan Terebralia sulcata dengan memanjat batang dan akar mangrove.

Kondisi kesehatan mangrove di Kelurahan Tafaga pada klaster 1 dan 2 memiliki status kesehatan baik. Klaster 3 dan 4 dengan status kondisi jelek sedangkan klaster 5 dengan status kondisi sedang. Sedangkan di Kelurahan Figur pada klaster 2 dan 3 memiliki status kesehatan baik, Klaster 4 dan 5 dengan status kondisi jelek dan klaster 1 dengan kondisi sedang. Kriteria kondisi kesehatan hutan mangrove yaitu 0,30 - 0,79 (kondisi jelek), 0,77 - 1,20 (kondisi sedang) dan 1,20 - 1,65 (kondisi baik) (Sari et al., 2019). Status kesehatan hutan mangrove baik Kelurahan Tafaga maupun Kelurahan Figur memiliki kondisi $60 \%$ baik, $20 \%$ dengan kondisi sedang dan kondisi jelek. Ini menunjukkan bahwa kondisi hutan mangrove di kedua lokasi penelitian masih tergolong baik. Kondisi ini dipengaruhi oleh ditemukannya 18 jenis fauna yang terdiri dari 14 jenis epifauna dan 4 jenis burung.Kondisi kesehatan hutan mangrove disajikan pada Tabel 4 dan 5.

Tabel 4. Kondisi kesehatan hutan mangrove Kelurahan Tafaga

\begin{tabular}{cccccc}
\hline \multirow{2}{*}{$\begin{array}{c}\text { Klaster } \\
\text { plot }\end{array}$} & $\mathrm{H}^{\prime}$ & $\begin{array}{c}\text { Skor } \\
\text { (NS) }\end{array}$ & $\begin{array}{c}\text { Tertimbang } \\
(\mathrm{NT})\end{array}$ & $\begin{array}{c}\text { Kondisi kesehatan } \\
\text { hutan mangrove } \\
(\text { NKHm) }\end{array}$ & Stasus Kesehatan Hutan Mangrove \\
\hline 1 & 2.12 & 5 & 0.33 & 1.65 & Baik \\
2 & 1.95 & 4 & 0.33 & 1.32 & Baik \\
3 & 1.76 & 2 & 0.33 & 0.66 & Jelek \\
4 & 1.57 & 1 & 0.33 & 0.33 & Jelek \\
5 & 1.78 & 3 & 0.33 & 0.99 & Sedang \\
\hline
\end{tabular}

Tabel 5. Kondisi kesehatan hutan mangrove Kelurahan Figur

\begin{tabular}{cccccc}
\hline \multirow{2}{*}{$\begin{array}{c}\text { Klaster } \\
\text { plot }\end{array}$} & H' & Nilai & Stasus \\
\cline { 2 - 5 } & $\mathrm{H}^{\prime}$ & Skor (NS) & Tertimbang (NT) & $\begin{array}{c}\text { Kondisi kesehatan hutan } \\
\text { mangrove (NKHm) }\end{array}$ & $\begin{array}{c}\text { Kesehatan Hutan } \\
\text { Mangrove }\end{array}$ \\
\hline 1 & 2.60 & 3 & 0.33 & 0.99 & Sedang \\
2 & 3.01 & 5 & 0.33 & 1.65 & Baik \\
3 & 2.71 & 4 & 0.33 & 1.32 & Baik \\
4 & 2.41 & 2 & 0.33 & 0.66 & Jelek \\
5 & 2.22 & 1 & 0.33 & 0.33 & Jelek \\
\hline
\end{tabular}


Keanekaragaman fauna berupa burung dan epifauna digunakan sebagai indikator kesehatan hutan mangrove karena burung bersifat dinamis dan memiliki penyebaran yang luas sehingga selalu merespon perubahan lingkungan (Gafur et al., 2016). Sedangkan keberadaan makrobentos dipengaruhi oleh perubahan kualitas air dimana apabila habitatnya tercemar, maka mempengaruhi komposisi dan kelimpahannya (Muhammad et al., 2017).

Kelompok moluska mangrove sangat mendukung fungsi ekologis hutan mangrove. Famili Potamididae, Neritidae, dan Cerithidae menjadikan kawasan mangrove sebagai tempat hidupnya (Insnaningsih dan Patria, 2018). Biodiversitas fauna memiliki hubungan positif dengan tingkat kesehatan, semakin baik tingkat biodiversitas yang dimiliki dalam hutan, maka tingkat kesehatan hutanpun akan meningkat (Safe'i et al., 2019).

\section{Kesimpulan}

Komposisi jenis mangrove sebanyak 9 jenis yaitu Avicennia offincinalis, A. Marina, Nypa fruticans, Rhizophora apiculata, $R$. stylosa, $R$. mucronata, Bruguiera gymnorrhiza, Sonneratia alba, Xylocarpus granatum, sedangkan komposisi jenis fauna sebanyak 18 jenis yang terdiri dari Epifauna (Gastropoda $=12$ jenis, Bivalva $=2$ jenis) dan burung sebanyak 4 jenis. Keanekaragaman jenis fauna hutan mangrove kategori sedang dan tidak ada jenis yang mendominasi. Status kesehatan hutan mangrove baik Kelurahan Tafaga maupun Kelurahan Figur memiliki kondisi $60 \%$ baik, $20 \%$ dengan kondisi sedang dan kondisi jelek.

\section{References}

Abubakar, S \& A. Achmad (2013). Tumbuhan Air (Panduan Pengajaran). LepKhair. Universitas Khairun. Ternate.

Abubakar, S., R. Subur, Darmawaty, N. Akbar \& I. Tahir (2019). Kajian Kesesuaian, Daya Dukung, Dan Aktivitas Ekowisata Di Kawasan Mangrove Desa Tuada Kecamatan Jailolo Kabupaten Halmahera Barat. Jurnal Enggano. 4 (2) : 222-242.

Abubakar, S., Subur, R. Malik, F.R \& N. Akbar. (2020). Damage Level and Area Suitability
Of Mangrove In Small Island Indonesia. International Conference on Fisheries and Marine IOP Conf. Series: Earth and Environmental Science: 1 - 9. Doi: 10.1088/1755-1315/584/1/012037.

Abubakar, S, R. Subur, M. A. Kadir, Rina, A. Noman Susanto \& H. S. Suriandjo (2021). Vegetation Structure and Damage Level Mangrove Forest in Manomadehe Island, Subdistrict South Jailolo, North Maluku Province. Jurnal Biologi Tropis, 21 (1): $222 \quad-\quad 230 . \quad$ DOI: doi.org/10.29303/jbt.v21i1.2492

Angriana, P., B.S, Dewi \& G.D. Winarno (2018). Populasi dan pola sebaran burung kuntul besar (Egretta alba) di Lampung Mangrove Center. Jurnal Sylva Lestari, 6 (3): 73-80.

Apriliyani, Y., Safei, R. Kaskoyo, H. Wulandari, C. \& I. G. Febryano (2020). Analisis Penilaian Kesehatan Hutan Mangrove Di Kabupaten Lampung Timur. Jurnal Hutan Tropis, 8 (2) : $123-130$.

Chen, J., Chen, G., Gu, Y., Zhu, H. and Ye, Y., (2020). Fate of leaf litter in restored Kandelia obovata (SL) mangrove forests with different ages in Jiulong River Estuary, China. Restoration Ecology, 28(2), pp.369-377.

Dharma, B. (2005). Recent and Fossil Indonesian Shell. Conch Book. PT. Ikrar Mandiriabadi. Jakarta.

Dharmawan, I. W. E., Suyarso, Y. I. Ulumuddin, B. Prayudha \& Pramudji (2020). Panduan Monitoring Struktur Komunitas Mangrove Panduan Monitoring Di Indonesia. Pusat Penelitian Oseanografi Lembaga Ilmu Pengetahuan Indonesia. PT Media Sains Nasional. Bogor. 89 hal.

Gafur, A., L. Elhayat \& M. Ikhsan (2016). Asosiasi jenis burung pada kawasan hutan mangrove di anjungan kota palu. Jurnal Warta Rimba, 4(1): 42-48.

Hartati \& L. Harudu (2016). Identifikasi JenisJenis Kerusakan Ekosistem Hutan Mangrove Akibat Aktivitas Manusia di Kelurahan Lowulowu Kecamatan Lea-Lea 
Kota Baubau. Jurnal Penelitian Pendidikan Geografi, 1 (1) : 30 - 45.

Hasan, S., R. Serosero \& S. Abubakar (2019). Distribusi Vertikal dan Komposisi Moluska pada Ekosistem Hutan Mangrove di Gugusan Pulau-Pulau Sidangoli Kabupaten Halmahera Barat Provinsi Maluku Utara. Jurnal Agribisnis Perikanan, 13 (1): 29-3.

Hutama, H. F. R, R. Hartati \& A. Djunaedi (2019). Makrozoobenthos Gastropoda pada Vegetasi Mangrove di Pesisir Utara, Semarang. Buletin Oseanografi Marina, 8 (1): $37-43$.

Insnaningsih, N.R \& Patria, M.P. (2018). Peran komunitas moluska dalam mendukung fungsi kawasan mangrove di Tanjung Lesung, Pandeglang, Banten. Jurnal Biotropika, 6(2): 35-44

Mangold, R. (1997). Forest health monitoring: field methods guide (internationalindonesia). Washington DC, Amerika Serikat: USDA Forest Service.

Mardi, M., Anwari, S. \& Burhanuddin (2019). Keanekaragaman Jenis Gastropoda Di Kawasan Hutan Mangrove Di Kelurahan Setapuk Besar Kota Singkawang. Jurnal Hutan Lestari, 7 (1) : 379 - 389.

Muhammad, F., Izzati, M \& Mukid, A.M. (2017). Makrobenthos sebagai indikator tingkat kesuburan tambak di pantai utara Jawa Tengah. Jurnal Bioma, 19(1): 38-46.

Noor, Y. R., M. Khazali \& I N. N. Suryadiputra. (2012). Panduan Pengenalan Mangrove di Indonesia. Wetland International, Bogor.

Rondo, M. (2015). Metodologi Analisis Ekologi Populasi dan Komunitas Biota Perairan. Program Pascasarjana. Unsrat. Manado.
Rospita, J, Zamdial \& P. P. Renta (2017). Valuasi Ekonomi Ekosistem Mangrove Di Desa Pasar Ngalam Kabupaten Seluma. Jurnal Enggano, 2 (1): 115-128.

Rusdianti, K. \& Sunito, S. (2012). Konversi Lahan Hutan Mangrove Serta Upaya Penduduk Lokal Dalam Merehabilitasi Ekosistem Mangrove. Jurnal Sosialisasi Perdesaan, 6 (1): 1-17.

Safe'i, R. \& Tsani, K.M. (2016). Kesehatan Hutan: Penilaian Kesehatan Hutan Menggunakan Teknik Forest Health Monitoring. Yogyakarta: Plantaxia.

Safe'i, R., Wuladari, C., \& Kaskoyo, H. (2019). Penilaian Kesehatan Hutan Pada Berbagai Tipe Hutan Di Provinsi Lampung. Jurnal Sylva Lestari, 7(1): 95-109.

Sari, S.M. (2012). Jenis - Jenis Burung Hutan Mangrove Di Areal PT. Bina Ovivipari Semesta dan Sekitarnya. PT. BiOS Group. Sei Raya.

Sari, R. N., R. Safe'I \& D. Iswandaru (2019). Biodiversitas Fauna Sebagai Salah Satu Indikator Kesehatan Hutan Mangrove. Jurnal Perennial, 15 (2): 62-66.

Simbala, R. W., Walangitan, H. D \& C. Kepel. (2017). Valuasi Ekonomi Hutan Mangrove Di Tanjung Dudepo, Kecamatan Bolaang Uki, Kabupaten Bolaang Mongondow Selatan. Agri-SosioEkonomi Unsrat, 13 (3) : $87-96$.

Wahyudyawati, E., A.Rahardjanto \& S. Wahyuni. (2017). Analisis Hubungan Kerapatan Mangrove Terhadap Fungsi Nursery Ground Pada Kepiting Bakau (Scylla Sp) Di Hutan Mangrove Pantai Cengkrong Kabupaten Trenggalek.. Program Studi Pendidikan Biologi-FKIP Universitas Muhammadiyah Malang. Prosiding seminar nasional III : $294-299$. 